\title{
Genetic subdivision of a sea star with high dispersal capability in relation to physical barriers in a fjordic seascape
}

\author{
Mattias Sköld ${ }^{1,2, *}$, Stephen R. Wing ${ }^{1}$, Philip V. Mladenov ${ }^{1}$ \\ ${ }^{1}$ Department of Marine Science, University of Otago, PO Box 56, Dunedin, New Zealand \\ ${ }^{2}$ Present address: National Board of Fisheries, Department of Coastal and Freshwater Resources, Box 423, \\ 40126 Göteborg, Sweden
}

\begin{abstract}
We used allozymes to investigate the population genetics of the sea star Coscinasterias muricata throughout New Zealand, with emphasis on populations inhabiting the fjords on the west coast of the South Island. Mean genetic variability measured by Wright's $F_{\mathrm{st}}$ for all the New Zealand populations was 0.061, indicating a moderate level of genetic divergence on a New Zealand wide scale. $F_{\mathrm{st}}$ for populations from the fjord region was generally lower, ranging from 0.024 to 0.028 , but it deviated from zero for all the loci examined. Evidence of isolation by distance was found when all populations were used in an analysis of log of the extent of gene flow between a pair of populations $(\hat{M})$ against the log of geographic distance $\left(\mathrm{r}^{2}=0.57, \mathrm{p}<0.001\right.$, Mantel test $)$. Thus, a pattern of isolation by distance seems evident on this larger scale. However, pair-wise comparisons of genetic distances, measured as $F_{\mathrm{st}}$, of populations on the regional scale of the fjords on the west coast of the South Island showed no correlation, since high variation of $F_{\text {st }}(0.001$ to 0.09$)$ between populations separated by 20 to $105 \mathrm{~km}$ was detected. The overall pattern of genetic variation revealed in a cluster analysis of genetic identity, $I$, grouped all the fjord populations together with maximum genetic identities of $94.6 \%$ to the other South Island populations, but within the fjord region, populations were not segregated according to geographical location. We suggest that the relatively isolated hydrography of each fjord is a most likely explanation for why fjord populations form genetic clusters that are inconsistent with geographical distance. The New Zealand fjords changed from freshwater systems about 12000 to $6500 \mathrm{yr}$ ago, and genetic equilibrium for the populations that colonized the fjords may not have been reached yet. We suggest that the recent colonization of the fjords, and the physical isolation from the open coast and each other, are important in explaining the genetic pattern of fjord populations of C. muricata.
\end{abstract}

KEY WORDS: Echinodermata $\cdot$ Coscinasterias muricata $\cdot$ Asexual/clonal reproduction $\cdot$ Larval dispersal $\cdot$ Isolation by distance $\cdot$ Island model $\cdot$ Estuarine circulation

\section{INTRODUCTION}

Theories on speciation processes frequently invoke isolating mechanisms, the most obvious being physical barriers e.g. islands and lakes, suggesting an allopatric mechanism for speciation (Dobzhansky 1937, Mayr 1942). It is thus not surprising that genetic differentiation among populations of species with planktotrophic larvae is typically low, since there can be gene flow among sub-populations even over large distances, and for these species mechanisms for allopatric speciation are rare. However, speciation events in marine phyla with dispersive larval forms, e.g. echinoderms (Emlet et al. 1987), is common enough that such taxa are dominant groups. The generalization that speciation must be rare in marine taxa with high dispersal appears, therefore, to be incorrect (Palumbi 1994).

At the mesoscale $(<1000 \mathrm{~km})$, physical barriers to dispersal of long-lived, planktotrophic larvae are rare, and raise the question about conditions that favour 
genetic divergence and speciation in groups with high dispersal potential. Episodic conditions may change patterns in gene flow and cause substantial divergence and speciation. An example of this is the rapid diversification of the genus Littorina in the north Atlantic following colonization after climatic changes during the upper Pliocene (Reid 1990). Other barriers may evolve at geological time-scales such as the closure of the Panama isthmus and the isolation and diversification of species in the Caribbean (e.g. Lessios \& Cunningham 1990, Lessios \& Weinberg 1993). However, Knowlton et al. (1993) concluded from ecological, geological and genetic data that gene flow over the Panama isthmus was disrupted several million years before the closure was complete, arguing that a circulatory barrier was in place during this period. In 2 studies, Benzie (1999) and Barber et al. (2000) concluded that between-ocean genetic differentiation of the sea star Acanthaster planci and the mantis shrimp Haptosquilla pulcella, each with 2 to 6 wk planktonic larvae phases, probably arose during Pleistocene low sea-level stands when the Pacific and Indian Ocean basins were isolated.

There is evidence of differentiation in local populations despite a larval dispersive stage (see review in Hedgecock 1986). This may occur as the result of physical barriers such as patterns of coastal or estuarine circulation (Scheltema 1975, Burton \& Feldman 1981, Johnson et al. 1986, Ayvazian et al. 1994). For example, some species inhabiting relatively closed embayments or isolated islands have shown greater than expected genetic divergence (Johnson et al. 1994, Parsons 1996). Transplant experiments indicate that limited dispersal in estuaries with low flushing rates may lead to restricted gene flow and adaptation to local conditions (Bertness \& Gaines 1993). Jones et al. (1999) and Swearer et al. (1999), using tagging and trace element techniques, showed that planktonic fish larvae stayed close to their natal sites on reefs, adding convincing evidence that oceanic conditions and larval behaviour can favour retention.

New Zealand's 14 spectacular deep-water fjords contain unique and fragile marine benthic communities of national and international significance due to unusually high species diversity and a high proportion of endemic, rare and protected species (Grange et al. 1981, Smith \& Witman 1999). The New Zealand fjords provide a unique natural laboratory in which to study evolutionary processes associated with the effects of isolation and its effects on gene flow in marine systems. Such opportunities are rare in the marine environment, which has been characterized as lacking of barriers responsible for genetic partitioning of populations (Knowlton 1993).

The aim of this study is to use the natural fjordic seascape of New Zealand's west coast to assess the importance of physical barriers in the marine environment on genetically isolating a species with high larval dispersal capability: the common sea star Coscinasterias muricata. These fjords present a situation that would allow such a comparative analysis in a replicated system. The 14 deep-water fjords together span over $200 \mathrm{~km}$ of the SW coastline of New Zealand's South Island. Characteristics of the fjords are that they are long (10 to $44 \mathrm{~km})$, narrow (0.7 to $2.3 \mathrm{~km})$, steepsided, and have 1 or more shallow (30 to $145 \mathrm{~m}$ ) sills between the deepest basin of the fjord and the open coast (Stanton \& Pickard 1981). Recent studies suggest that the fjords were freshwater lake systems ca. $18000 \mathrm{yr}$ ago, when sea level was about $100 \mathrm{~m}$ below present (Pickrill et al. 1992). The fjords were inundated with seawater ca. 12000 to $6500 \mathrm{yr}$ ago, when sea level began to rise, at which time adjacent marine populations may have colonized them.

The hydrography of the fjords is strongly influenced by orographic rainfall (up to $7 \mathrm{~m} \mathrm{yr}^{-1}$ ) in the area that results in a seawardly flowing surface low salinity layer (LSL) typically down to 2-10 $\mathrm{m}$, which drives a 2-layer estuarine circulation of variable strength in each fjord. As the LSL flows seaward, saltwater is mixed across the halocline and advected out of the fjord. Maintenance of salt balance occurs by a very slow injection of seawater into the fjord below the LSL. Because the net flow of seawater is inward, planktonic larvae may be retained within natal fjords (Lamare 1998). Although larvae with long duration and large potential dispersal distance are theoretically able to exit the fjords via the LSL, they likely perish due to the low salinity conditions within the LSL.

We predict that the New Zealand fjords will exert a range of effects on larval dispersal and gene flow in native coastal marine organisms, and therefore play an important role in shaping the population genetic structure and evolution of these species. Support for this hypothesis comes from a study using allozymes of the sea urchin Evechinus chloroticus, that exhibits low genetic distances between populations but significant genetic distances between a fjord population and coastal populations (Mladenov et al. 1997).

\section{MATERIALS AND METHODS}

Natural history of Coscinasterias muricata. C. muricata (Fig. 1) is widely distributed within the Indo-Pacific region, and is the most common sea star in New Zealand waters. It occupies both intertidal and subtidal habitats, but is usually restricted to sheltered sites such as harbours and wave-protected shores (Barker 1977). It is a critical predator, especially in the subtidal communities of New Zealand fjords (Witman \& Grange 1998). Spawn- 


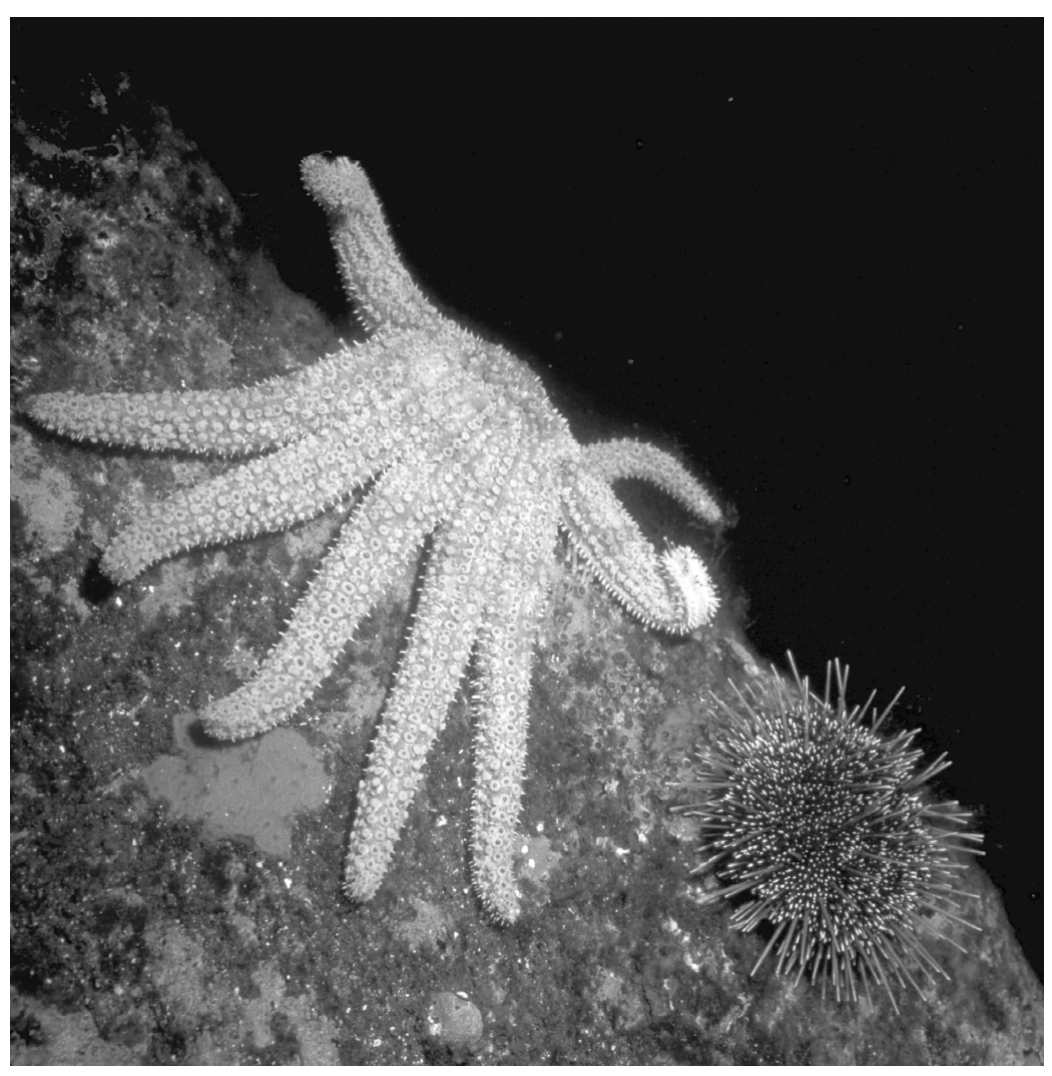

Fig. 1. Sea star Coscinasterias muricata and the sea urchin Evechinus chloroticus in Doubtful Sound, New Zealand ing is seasonal and occurs between November and March (Crump \& Barker 1985). C. muricata has a free-swimming brachiolaria larva, and the planktonic stage has been inferred from laboratory culture to be about 30 d (Barker 1978). Sexual recruitment is irregular, and in addition to sexual reproduction, $C$. muricata propagate asexually through fission (Crump \& Barker 1985, Johnson \& Threlfall 1987). However, not all populations show signs of fission, and no evidence of asexual reproduction has been observed in the fjords of the South Island of New Zealand (Sköld et al. 2002).

Sample collection. Sea stars were sampled from 13 fjords populations on the South Island of New Zealand during a two 2 wk long cruise aboard the MV 'Renown' in May 1998. Samples were also collected from the North Island, the east coast of the South Island, and Stewart Island. In summary, samples of 24 to 70 individuals of Coscinasterias muricata were obtained from 16 sites from January to September 1998 (Fig. 2). Those from the fjords and Stewart Island were

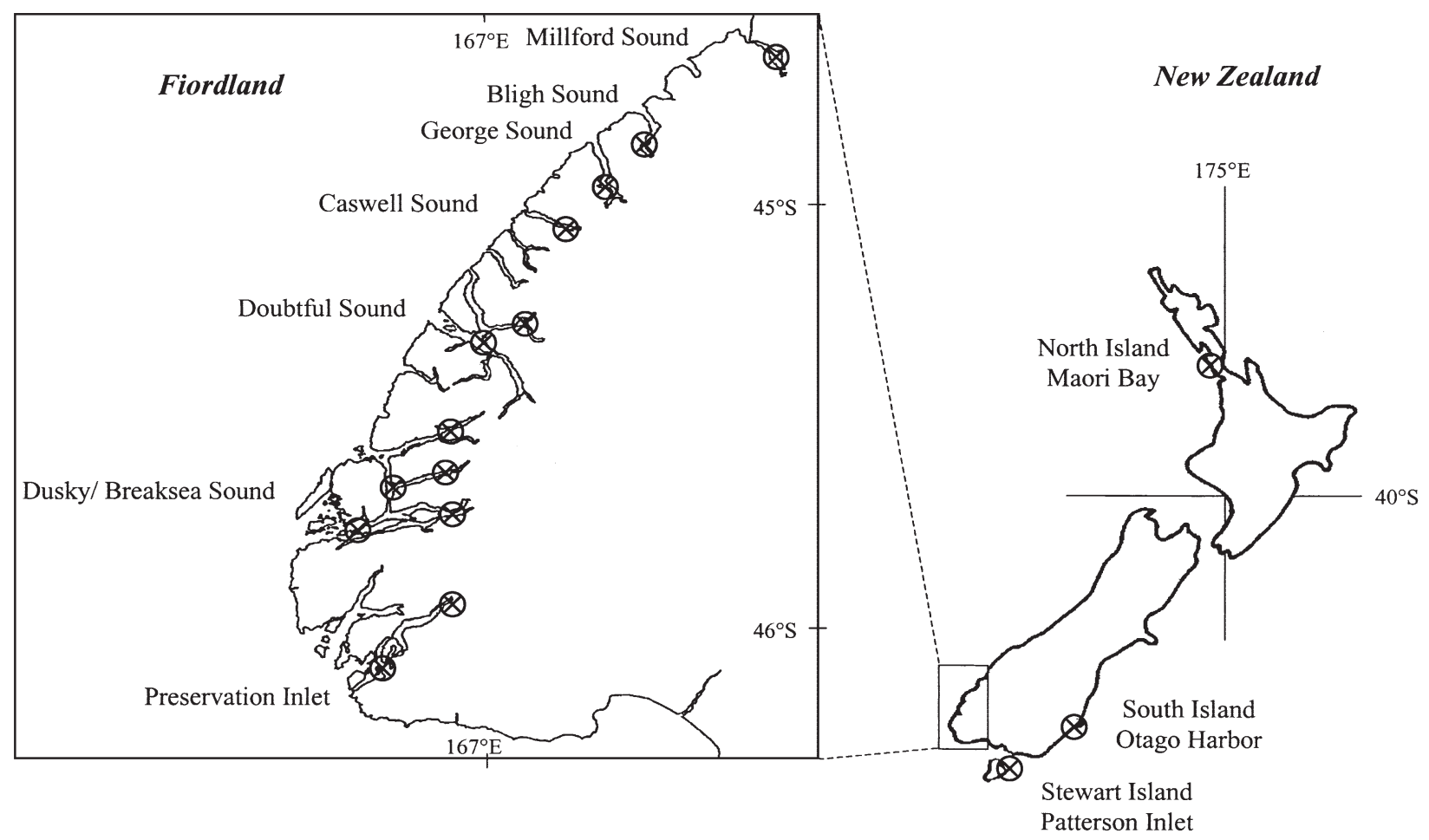

Fig. 2. Locations of study sites of Coscinasterias muricata on the North Island, South Island, and Stewart Island, New Zealand 
sampled from depths of 2 to $10 \mathrm{~m}$, and those from the east coast, Otago Harbour and the North Island, Maori Bay, were sampled among rocks and boulders in the lower intertidal. Subtidal sea stars were brought by divers to the surface and kept alive until dissection. Tissue samples were taken from tube feet and pyloric caeca, stored in $1.5 \mathrm{ml}$ Eppendorf tubes, and immediately frozen in liquid nitrogen on board the research vessel. In the laboratory samples were stored at $-80^{\circ} \mathrm{C}$ pending analysis. On all seastars, length of the longest $\operatorname{arm}(R)$ was measured from the centre of the disk to the tip of the arm and number of arms and madreporites counted. Appearance of being split was assessed by asymmetry, i.e. if the disk appeared to have split and several (>2) proximate arms were regenerating.

Electrophoresis. Samples of tube feet and pyloric caeca were prepared for electrophoresis by grinding the tissue in 1 to 6 drops of homogenizing buffer; $0.02 \mathrm{M}$ tris, $0.1 \%(\mathrm{w} / \mathrm{v})$ mercaptoethanol $0.1 \%(\mathrm{w} / \mathrm{v})$ bromophenolblue, $\mathrm{pH}=7.5$. Samples were then centrifuged for 3 (tube feet) or 8 (pyloric caeca) min at $4500 \mathrm{rpm}(5000 \times \mathrm{g})$. Wicks of filter paper were then soaked in the supernatants for running on starch gels $(12 \% \mathrm{w} / \mathrm{v})$ using lithium hydroxide $(\mathrm{LiOH})$ or trismaleate (TM) buffers (Buffers 2 and 9, respectively, according to Selander et al. 1971). A preliminary survey of 15 enzyme systems revealed 4 polymorphic enzymes, which could be scored efficiently. TM-buffer and tube-feet tissue were used to score phosphoglucose isomerase (Pgi, EC 5.3.1.9), phosphoglucomutase (Pgm, EC 5.4.2.2), and malate dehydrogenase (Mdh-2, EC 1.1.1.37). LiOH-buffer and pyloric caeca tissue were used to score hexokinase (Hk, EC 2.7.1.1). Two enzymes, malate dehydrogenase (Mdh-1) and superoxide dismutase (Sod), showed monomorphism, and were not further analyzed. Staining techniques were based on those of Pasteur et al. (1988) and Shaw \& Prasad (1970). Alleles were labelled alphabetically, in order of decreasing electrophoretic mobility of their corresponding allozymes.

Analyses. Departures of genotypic frequencies from Hardy-Weinberg equilibrium for each locus in each sample are presented as values of $H_{\mathrm{d}}$, where $H_{\mathrm{d}}=\left(H_{\mathrm{o}}-\right.$ $\left.H_{\mathrm{e}}\right) / H_{\mathrm{e}} . H_{\mathrm{o}}$ is the observed number, and $H_{\mathrm{e}}$ is the expected number of heterozygotes. Statistical significance of departures was tested, and combined for each site by the exact Hardy-Weinberg test of Haldane (1954), using the program GENEPOP 3.1b (Raymond \& Rousset 1995).

Occurrence of asexual reproduction was analyzed as the number of multilocus genotypes observed and the genotypic diversity, $G_{0}$ according to Stoddart (1983). The expected diversity, $G_{\mathrm{e}}$, under Hardy-Weinberg equilibrium for the same allelic composition, was determined by simulation of sampling from a population with random mating, using an average of 500 runs. The value of $G_{0}$ was tested against expectation with a Student's $t$-test for comparison of a single observation with the mean of a sample (Sokal \& Rohlf 1995).

Genetic correlations were described using the parameters $F_{\text {st }}$ (subdivision among populations) and $F_{\text {is }}$ (inbreeding within populations) of Wright (1978), using the estimators of Weir \& Cockerham (1984). Standard deviation and an unbiased $F_{\text {st }}$ were estimated by the jackknife procedure over loci, and confidence intervals by bootstrapping over loci according to Weir (1990). Tests of significance of $F_{\text {st }}$ and $F_{\text {is }}$ over all loci were done by permutations using the program FSTAT 1.2 (Goudet 1995). The extend of gene flow between a pair of populations $(\hat{M})$ was estimated assuming the island model under equilibrium from the unbiased $F_{\text {st }}$ using the equation $\hat{M}=N_{e} m=\left(1 / F_{\text {st }}-1\right) / 4$ of Slatkin (1993). This transformation of $F_{\text {st }}$ to $M$ does not necessarily provide an accurate estimate of gene flow due to several underlying assumptions that are unlikely met (see 'Discussion'), but was done for the purpose of analyzing isolation by distance. The relationship between $\log$ distance and $\log \hat{M}$ was evaluated using the Mantel test (Mantel 1967). Given the pattern of isolation by distance, the number of migrants between generations among all sites was estimated using the estimate from a stepping stone model by Crow \& Aoki (1984) as $N m=\left(\left[1-F_{\text {st }}\right][-\ln 2 \mu]\right) / 4$, where $\mu$ is the mutation rate, assumed to be $10^{-7}$ (see Table 2).

Unbiased genetic identities $(I)$ and distances $(D)$ were calculated according to Nei (1978). Genetic identities were clustered by the unweighted pair-group method with arithmetic averaging (UPGMA) using the program BIOSYS-1 1.7 (Swofford \& Selander 1989).

\section{RESULTS}

Mean sizes, based on $R$, of the Coscinasterias muricata populations in the fjords are shown in Fig. 3. Sizes were, in general, unimodal within sites but differed significantly between sites in the fjords (ANOVA, $\left.F_{16,796}=178.3, \mathrm{p}=0.0001\right)$. Smaller specimens were rarely found in the fjords, and when present they usually occurred cryptically under rocks and boulders. Few or no $C$. muricata were encountered at the exposed entrances of the fjords. In the population sampled at North Island, Maori Bay, a wider range of sizes was found ( $R=62.6 \pm 22.4)$, and in Otago Harbour all specimens were small $(R=23.6 \pm 9.7$, Fig. 3$)$.

The populations from North Island, Maori Bay and Otago Harbour frequently showed characteristics of having undergone fission. Numbers of madreporites were, respectively, $2.4(\mathrm{SD}=1.0)$ and $1.8(\mathrm{SD}=0.7)$. Based on asymmetry, i.e. that the disk had split and 


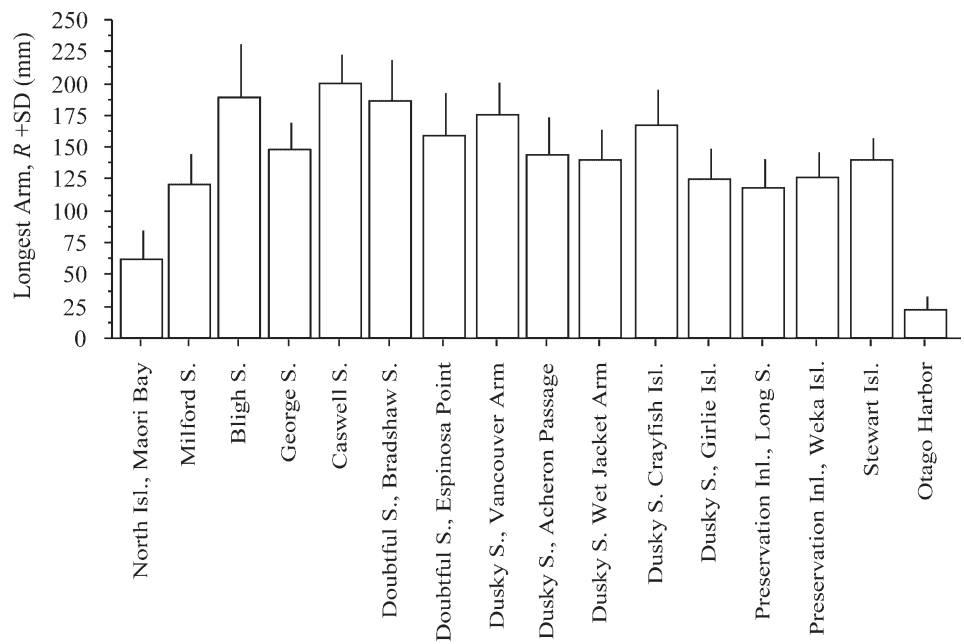

Fig. 3. Mean size distribution of Coscinasterias muricata from all populations using longest arm, $R+\mathrm{SD}$
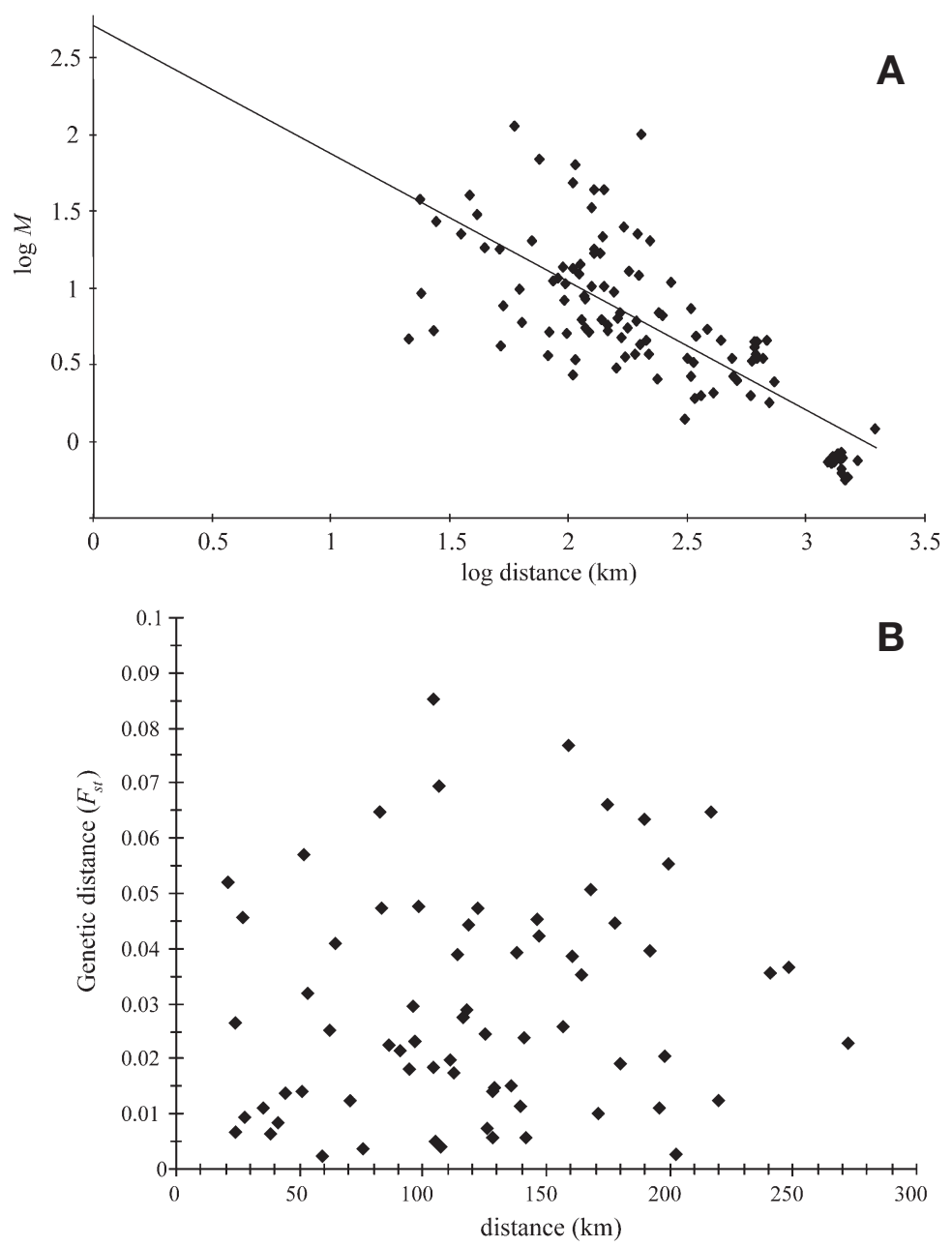

Fig. 4. Coscinasterias muricata. (A) Regression $(y=2.675-0.826 x$; $\left.\mathrm{r}^{2}=0.57\right)$ of log gene flow $(\hat{M})$ versus log distance $(\mathrm{km})$ of separation for all pair-wise populations; $(B)$ genetic distance $\left(F_{\mathrm{st}}\right)$ versus geographic distance of separation $(\mathrm{km})$ for all pair-wise combinations between the fjords several arms were under regeneration, we estimated that $92 \%$ had recently undergone fission in the North Island population, and $100 \%$ in Otago Harbour. In contrast, we did not observe any characters indicating that fission had occurred in the fjord populations or at Stewart Island.

Of the 15 loci examined, only 4 were polymorphic: Pgi, Pgm, Hk and Mdh-2. Pgm was the most variable with 1 fast allele frequently occurring in the North Island population, but observed only once from all the other populations. Pgi was also variable with up to 4 alleles, of which 3 were rather common and 1 fast was rare, but found at low frequency in all except 5 of the 16 populations studied. For the Hk-locus, 2 common alleles and 2 rare alleles were present, and 1 of these occurred only once in all the populations examined. Two alleles were present at the Mdh-2 locus, 1 of them being dominant in all the populations (Table 1).

Strong deviations from Hardy-Weinberg expectations were found at 2 loci in the North Island, and at 3 loci from the Otago Harbour populations. Deviations were also found at 1 locus for 5 of the 13 fjord populations (Table 1). Four of those were for the $H k$ locus because of a heterozygote deficit for this locus (Table 1). None of the fjord populations had a significantly lower ratio of observed versus expected genotypic diversity. In contrast, this ratio was significantly lower than expected for the North Island and the Otago Harbour populations, thus confirming the observations of frequent asexual reproduction by fission in these populations (Table 1).

As asexual reproduction was frequent in the North Island and Otago Harbour populations, only unique 4-locus genotypes from these populations were used when analyzing genetic variance and identities. This resulted in a decrease in deviation from Hardy-Weinberg expectation for the Pgi and Pgm loci for the Otago Harbour population and the Pgi and Hk loci of the North Island population. The average $F_{\text {st }}$ for all the populations was 0.061 , indicating moderate genetic divergence over this large distance. The largest $F_{\text {st }}$ of 0.17 was found for the Pgm locus, and due to the fast allele occurring frequently in the North Island population. The $F_{\mathrm{st}}$ for the fjords was generally lower, ranging from 0.024 to 0.028 , but deviated significantly from zero for all the loci examined (Table 2). Indication of isolation by distance was found using all populations in a $\log \hat{M}$ against the $\log$ of geographic distance (Fig. 4A; $\mathrm{r}^{2}=0.57, \mathrm{p}<0.001$, Mantel test). Pair-wise comparisons of genetic distances, measured as $F_{\mathrm{st}}$ of populations on the regional scale of the fjords on the west coast of 
South Island showed high variation and no correlation to geographical distance (Fig. 4B).

The cluster analysis of genetic identity, $I$, shown in Fig. 5, revealed the overall genetic pattern of genetic variation. All the fjords clustered together, with average identities of $94.6 \%$ for Otago Harbour and Stewart Island (genetic distance $D=0.053$ ), and $73.7 \%$ $(D=0.304)$ for the North Island population, thus visualizing the pattern of isolation by distance on this larger scale. In contrast, the populations within the fjords were not segregated according to location within geographical regions, as exceptions occurred in all the 3 major groups that clustered together (Fig. 5).

\section{DISCUSSION}

We examined New Zealand-wide $(>1000 \mathrm{~km})$ and regional $(<200 \mathrm{~km})$ genetic variation in Coscinasterias muricata, a sea star with high larval dispersal ability.
The results showed moderate genetic variance, $F_{\text {st }}$ on the larger New Zealand scale. Species with extended planktotrophic development generally show little genetic divergence, $F_{\mathrm{st}}=0.004$ to 0.02 , over distances comparable to this study, i.e. 1000 to $4000 \mathrm{~km}$ (Johnson \& Black 1984, Watts et al. 1990, Benzie \& Stoddart 1992, Williams \& Benzie 1993, Hollborn et al. 1994, Mladenov et al. 1997). In comparison to these figures, the mean $F_{\text {st }}$ of 0.061 of $C$. muricata found in this study approaches the range which is found in some lecithotrophic developers: 0.076 to 0.091 (Maestro et al. 1982, Parsons 1996). Part of the genetic variation is due to a fast allele at the Pgm locus in the North Island population that occurs only for 1 individual in all the other populations, but significant variation is due to the populations in the fjords on the New Zealand west coast $\left(F_{\mathrm{st}}=0.025\right)$. These findings suggest that there are likely restrictions on gene flow between the populations of C. muricata considered in this study.

Table 1. Coscinasterias muricata. Allele frequencies for the 4 polymorphic loci screened in 16 populations of $C$. muricata from New Zealand. Localities are listed from north to south; $H_{\mathrm{d}}$, degree of departure of genotypic frequencies from Hardy-Weinberg expectations; $G_{0}$ and $G_{\mathrm{e}}$ observed and expected genotypic diversity, respectively; n, number of individuals scored. Numbers in brackets are corrected for potential clone mates, i.e. only unique 4 locus genotypes. Significant deviation from expected indicated as: ${ }^{*} \mathrm{p}<0.05_{i}{ }^{* *} \mathrm{p}<0.01 ;{ }^{* * *} \mathrm{p}<0.001$

\begin{tabular}{|c|c|c|c|c|c|c|c|c|}
\hline $\begin{array}{l}\text { Locus } \\
\text { allele }\end{array}$ & $\begin{array}{cc}\text { s, } & \text { North Island } \\
\text { Maori Bay }\end{array}$ & $\begin{array}{l}\text { Stewart Island } \\
\text { Patterson Inlet }\end{array}$ & $\begin{array}{l}\text { Otago Harbour } \\
\text { Vauxhall }\end{array}$ & $\begin{array}{l}\text { Millford } \\
\text { Sound }\end{array}$ & $\begin{array}{l}\text { Bligh } \\
\text { Sound }\end{array}$ & $\begin{array}{l}\text { George } \\
\text { Sound }\end{array}$ & $\begin{array}{l}\text { Caswell } \\
\text { Sound }\end{array}$ & $\begin{array}{l}\text { Doubtful Sound } \\
\text { Bradshaw Sound }\end{array}$ \\
\hline \multicolumn{9}{|l|}{ Pgi } \\
\hline $\mathrm{n}$ & $38(26)$ & 38 & $42(17)$ & 48 & 32 & 42 & 40 & 40 \\
\hline A & $0.066(0.058)$ & - & - & 0.010 & - & 0.036 & 0.038 & 0.013 \\
\hline B & $0.211(0.250)$ & 0.355 & $0.107(0.147)$ & 0.479 & 0.531 & 0.393 & 0.313 & 0.425 \\
\hline $\mathrm{C}$ & $0.289(0.308)$ & 0.592 & 0.607 (0.588) & 0.323 & 0.156 & 0.345 & 0.400 & 0.325 \\
\hline $\mathrm{D}$ & $0.434(0.385)$ & 0.053 & $0.286(0.265)$ & 0.188 & 0.313 & 0.226 & 0.250 & 0.238 \\
\hline$H d$ & $0.109(0.091)$ & -0.202 & $-0.388^{* *}(-0.290)$ & 0.046 & 0.239 & 0.012 & 0.019 & -0.023 \\
\hline \multicolumn{9}{|l|}{ Pgm } \\
\hline $\mathrm{n}$ & $39(26)$ & 41 & $40(17)$ & 48 & 32 & 41 & 40 & 40 \\
\hline $\mathrm{A}$ & $0.128(0.115)$ & - & - & - & - & - & - & - \\
\hline B & $0.744(0.692)$ & 0.037 & $0.025(0.059)$ & - & - & 0.012 & - & - \\
\hline $\mathrm{C}$ & $0.128(0.192$ & 0.915 & $0.575(0.618)$ & 0.896 & 0.875 & 0.854 & 0.750 & 0.825 \\
\hline $\mathrm{D}$ & - & 0.049 & $0.400(0.324)$ & 0.104 & 0.125 & 0.134 & 0.250 & 0.175 \\
\hline$H d$ & $0.100(0.124)$ & 0.056 & $0.553^{* * *}\left(0.230^{* *}\right)$ & -0.116 & -0.156 & -0.239 & -0.078 & 0.197 \\
\hline \multicolumn{9}{|l|}{$H \boldsymbol{k}$} \\
\hline $\mathrm{n}$ & $40(26)$ & 41 & $50(17)$ & 48 & 33 & 46 & 42 & 40 \\
\hline $\mathrm{A}$ & - & - & - & - & - & - & - & - \\
\hline B & $0.113(0.154)$ & 0.268 & $0.240(0.324)$ & 0.521 & 0.545 & 0.467 & 0.690 & 0.475 \\
\hline $\mathrm{C}$ & $0.713(0.654)$ & 0.646 & $0.680(0.559)$ & 0.469 & 0.455 & 0.533 & 0.298 & 0.525 \\
\hline $\mathrm{D}$ & $0.175(0.192)$ & 0.085 & $0.080(0.118)$ & 0.010 & - & - & 0.012 & - \\
\hline$H d$ & $0.045^{*}(0.032)$ & -0.090 & $-0.247^{*}(-0.298)$ & $-0.473^{* * *}$ & -0.157 & $-0.352^{*}$ & -0.080 & -0.109 \\
\hline \multicolumn{9}{|c|}{ Mdh-2 } \\
\hline $\mathrm{n}$ & $39(26)$ & 38 & $41(17)$ & 48 & 32 & 41 & 40 & 38 \\
\hline $\mathrm{A}$ & $0.833(0.788)$ & 0.842 & $0.988(0.971)$ & 0.813 & 0.859 & 0.939 & 0.863 & 0.895 \\
\hline B & 0.167 (0212) & 0.158 & $0.012(0.029)$ & 0.188 & 0.141 & 0.061 & 0.138 & 0.105 \\
\hline$H d-$ & $-0.909^{* * *}\left(-0.888^{* * *}\right.$ & *) 0.172 & $0.000(0.000)$ & -0.083 & -0.109 & 0.052 & 0.145 & -0.173 \\
\hline$G_{\mathrm{o}}: G_{\mathrm{e}}$ & $0.630^{* * *}$ & 1.291 & $0.610^{* * *}$ & 1.081 & 0.956 & 1.160 & 1.228 & 1.150 \\
\hline
\end{tabular}


Table 1 (continued)

\begin{tabular}{|c|c|c|c|c|c|c|c|c|}
\hline \multirow{2}{*}{$\begin{array}{l}\text { Locus, } \\
\text { allele }\end{array}$} & \multirow{2}{*}{$\begin{array}{c}\text { Doubtful } \\
\text { Sound } \\
\text { Espinosa Point }\end{array}$} & \multicolumn{5}{|c|}{ - Dusky Sound } & \multicolumn{2}{|c|}{ _ Preservation Inlet _ } \\
\hline & & $\begin{array}{c}\text { Vancouver } \\
\text { Arm }\end{array}$ & Acheron & Wet Jacket & Crayfish & Girlie & Long & Weka \\
\hline \multicolumn{9}{|l|}{$P g i$} \\
\hline $\mathrm{n}$ & 76 & 40 & 49 & 42 & 24 & 40 & 41 & 40 \\
\hline A & 0.026 & 0.025 & 0.010 & 0.012 & 0.042 & 0.013 & - & - \\
\hline $\mathrm{B}$ & 0.421 & 0.138 & 0.276 & 0.226 & 0.208 & 0.338 & 0.317 & 0.300 \\
\hline $\mathrm{C}$ & 0.322 & 0.450 & 0.306 & 0.333 & 0.313 & 0.350 & 0.402 & 0.463 \\
\hline $\mathrm{D}$ & 0.230 & 0.388 & 0.408 & 0.429 & 0.438 & 0.300 & 0.280 & 0.238 \\
\hline$H d$ & $-0.095^{* *}$ & 0.022 & -0.026 & -0.101 & 0.103 & 0.173 & -0.049 & 0.158 \\
\hline \multicolumn{9}{|l|}{ Pgm } \\
\hline $\mathrm{n}$ & 76 & 40 & 50 & 44 & 25 & 40 & 40 & 41 \\
\hline A & - & - & - & - & 0.020 & - & - & - \\
\hline B & - & 0.038 & 0.020 & 0.057 & 0.020 & 0.013 & - & - \\
\hline $\mathrm{C}$ & 0.868 & 0.875 & 0.930 & 0.864 & 0.900 & 0.863 & 0.938 & 0.988 \\
\hline $\mathrm{D}$ & 0.132 & 0.088 & 0.050 & 0.080 & 0.060 & 0.125 & 0.063 & 0.012 \\
\hline$H d$ & -0.084 & 0.096 & 0.048 & -0.081 & -0.155 & 0.130 & 0.053 & 0.000 \\
\hline \multicolumn{9}{|l|}{$H k$} \\
\hline $\mathrm{n}$ & 51 & 41 & 47 & 44 & 27 & 41 & 41 & 42 \\
\hline A & - & 0.012 & - & - & - & - & - & - \\
\hline B & 0.373 & 0.610 & 0.351 & 0.477 & 0.685 & 0.573 & 0.610 & 0.476 \\
\hline $\mathrm{C}$ & 0.588 & 0.354 & 0.596 & 0.500 & 0.315 & 0.415 & 0.366 & 0.500 \\
\hline $\mathrm{D}$ & 0.039 & 0.024 & 0.053 & 0.023 & - & 0.012 & 0.024 & 0.024 \\
\hline$H d$ & -0.168 & -0.233 & $-0.351^{* *}$ & -0.225 & -0.073 & $-0.421^{* *}$ & -0.219 & -0.100 \\
\hline \multicolumn{9}{|l|}{ Mdh } \\
\hline $\mathrm{n}$ & 68 & 39 & 50 & 44 & 25 & 41 & 41 & 41 \\
\hline A & 0.897 & 0.974 & 0.950 & 0.955 & 0.960 & 0.878 & 0.963 & 1.000 \\
\hline B & 0.103 & 0.026 & 0.050 & 0.045 & 0.040 & 0.122 & 0.037 & - \\
\hline$H d$ & -0.210 & 0.013 & -0.375 & 0.036 & 0.021 & -0.100 & 0.025 & - \\
\hline$G_{\mathrm{o}}: G_{\mathrm{e}}$ & 0.976 & 1.035 & 1.088 & 0.968 & 0.984 & 1.041 & 0.828 & 1.099 \\
\hline
\end{tabular}

Genetic differences between populations should accumulate if dispersal is restricted geographically. This 'isolation by distance' process, introduced by Wright (1943), proposes that gene flow occurs among local neighbourhoods in a continuously distributed population. Indeed, the $\log$ of $\hat{M}$ between pairs of localities of Coscinasterias muricata inversely correlated with the log of geographic separation and, on the larger scale, spatial separation between populations accounted for $57 \%$ of the genetic variation (based on $\mathrm{r}^{2}$ ). Isolation by distance has been shown in species with large distributions relative to their dispersal capability (e.g. Hellberg 1994, Palumbi et al. 1997, Johnson \& Black 1998). Possibly more importantly, however, are special conditions that might favour isolation
Table 2. Coscinasterias muricata. Summary of Weir \& Cockerham (1984) estimates of $F$-statistics at all sites around New Zealand $(\mathrm{n}=16)$, and the fjords $(\mathrm{n}=13)$. Also shown are the unbiased estimate of genetic variability measured by Wright's $F_{\text {st }}$ and $F_{\text {is }}$ with standard deviation and $95 \%$ confidence limits, the estimated number of migrants per generation between sites $(\mathrm{Nm})$, and mean and maximum distance between sites. ${ }^{* * *}$ Significant deviation from expected $F_{\text {st }}$ at $\mathrm{p}<0.001$

\begin{tabular}{|c|c|c|c|c|}
\hline \multirow[t]{2}{*}{ Locus } & \multicolumn{2}{|c|}{ All sites } & \multicolumn{2}{|c|}{ Fjords } \\
\hline & $F_{\text {st }}$ & $F_{\text {is }}$ & $F_{\mathrm{st}}$ & $F_{\text {is }}$ \\
\hline Pgi & 0.034 & $-0.005-$ & 0.024 & -0.021 \\
\hline Pgm & 0.170 & $-0.001-$ & 0.021 & 0.034 \\
\hline$H k$ & 0.048 & 0.223 & 0.026 & 0.243 \\
\hline$M d h-2$ & 0.031 & 0.104 & 0.028 & 0.054 \\
\hline Mean & $0.061^{* * *}$ & $0.081^{* * *}$ & $0.025^{* * *}$ & $0.081^{* * *}$ \\
\hline Unbiased mean & 0.056 & 0.077 & 0.025 & 0.075 \\
\hline SD & 0.025 & 0.082 & 0.001 & 0.097 \\
\hline $95 \% \mathrm{CI}$ & $0.034-0.122$ & $-0.004-0.194$ & $0.022-0.027$ & $-0.015-0.217$ \\
\hline $\mathrm{Nm}$ & \multicolumn{2}{|c|}{20693} & \multicolumn{2}{|c|}{9750} \\
\hline \multicolumn{2}{|c|}{ Maximum distance $(\mathrm{km})$} & 1955 & \multicolumn{2}{|c|}{272} \\
\hline Mean distance & \multicolumn{2}{|r|}{362} & \multicolumn{2}{|c|}{120} \\
\hline
\end{tabular}




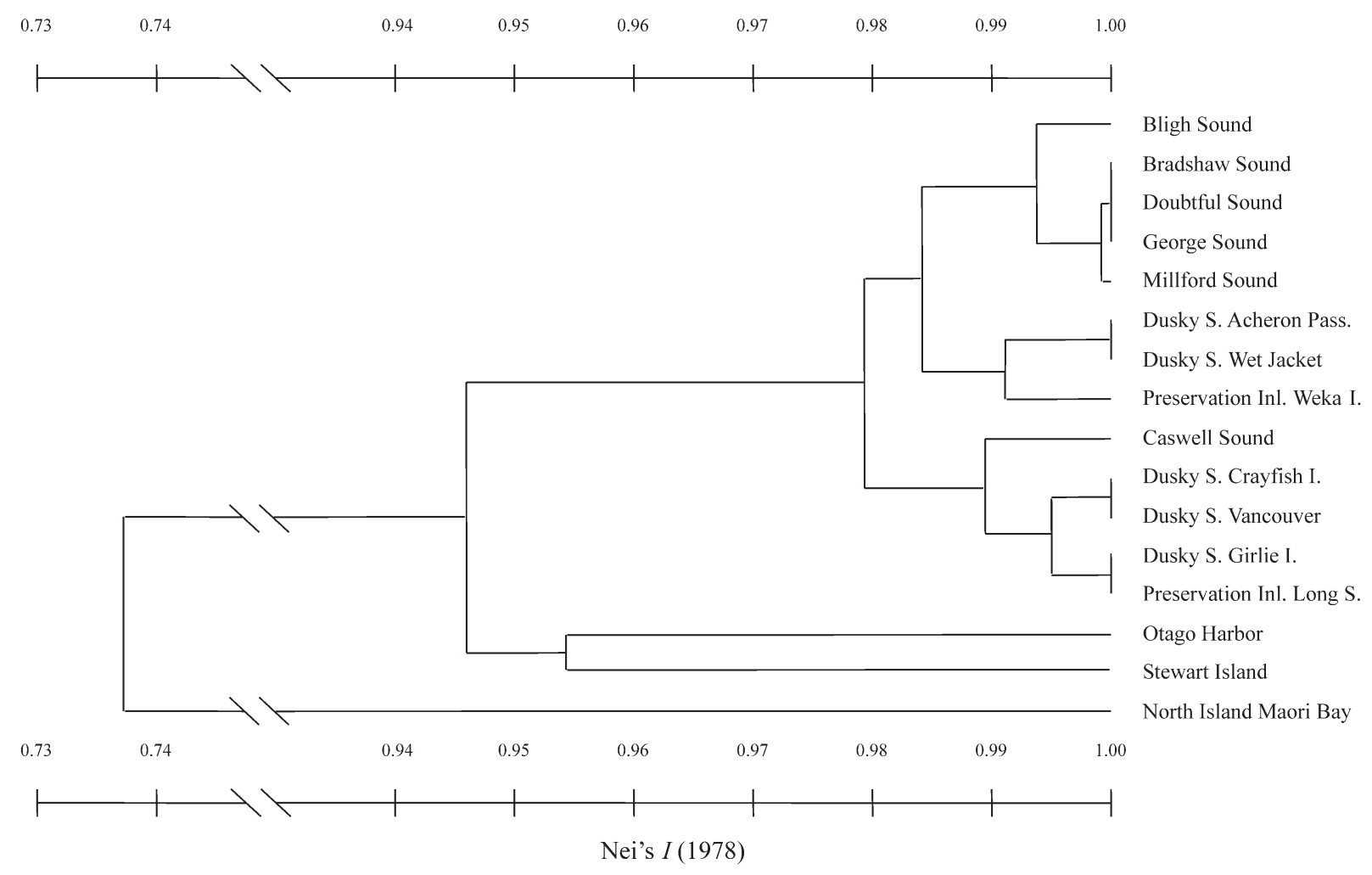

Fig. 5. Coscinasterias muricata. Phenetic dendrogram (UPGMA cluster) based on Nei's (1978) unbiased genetic identity, I, of the sea star based on 4 polymorphic loci. Cophenetic correlation $=0.979$

of populations within a widely distributed population. Pair-wise comparisons of genetic distances, measured as $F_{\text {st }}$ of populations on the regional scale of the fjords on the west coast of the South Island showed no correlation, and large residuals indicate that genetic drift is more influential than gene flow (Hutchinson \& Templeton 1999). In the clusteranalysis using genetic identity, $I$, all the fjord populations grouped together, but within the fjord cluster, fjords were not segregated according to geographical location. Measured as genetic distance, $D$, populations in the fjord region differed from those around Stewart Island and the east coast by 0.053, and from those on the North Island by 0.304 . Obvious exceptions occurred in 2 of the 3 major fjord groups that clustered together, e.g. the population from Caswell Sound in the north groups together with populations from the Dusky Sound region and the southernmost fjord, Preservation Inlet. These patterns suggest that populations in the fjords may be more isolated from each other than similarly spaced populations around New Zealand.

There are several alternative explanations for this pattern: the genetic markers (allozymes) used in this study may not be differentiated sufficiently to resolve real differences among populations; the mating system of Coscinasterias muricata may go against the assump- tions of a continuous population; natural selection could interfere with the pattern; the populations in the fjords may not have had time to reach genetic equilibrium since colonization; dispersal may occur over a spatial scale greater than the regional scale of the fjords; or the circulatory pattern of the fjords may act to isolate fjords from the open coast and between fjords (thus violating the assumption of a continuously distributed population, Wright 1943).

The power to detect genetic divergence depends on the number of loci studied. In this study, only 4 loci showed polymorphism and reliable results. However, the Hk locus showed departures from genotypic frequencies expected under Hardy-Weinberg equilibrium in 5 out of 16 populations, and should be considered with some care. In summary this may have limited our analysis. Johnson \& Threlfall (1987) used 6 polymorphic loci in a study on the same species. Two of the allozymes they used, esterase (Est) and leucyltyrosine peptidase (Ltp), showed inconclusive banding and could not be scored successfully in our lab, and superoxide dismutase (Sod) showed monomorphism. Several studies with allozymes in echinoderms used rather few (4 to 6 ) loci, as preliminary analyses show monomorphism for several loci (e.g. Johnson \& Threlfall 1987, Mladenov \& Emson 1990, Edmands et al. 1996, 
Garrett et al. 1997, Mladenov et al. 1997). The power to detect genetic divergence also depends on variability of the loci examined. All 4 polymorphic loci examined in our study showed significant variation both on the larger New Zealand scale and on the regional scale of the fjords, indicating that the data were sufficient to resolve patterns of genetic divergence.

Natural selection is a diversifying force and may underlie geographic variation at some allozyme loci (see review in Hedgecock 1986). In particular, the low salinity layers (LSL) of the fjords are an obvious source for selection of salinity tolerance. Koehn et al. (1984) demonstrated non-random genotype-dependent mortality after larval settlement in Mytilus edulis, and a stable cline in aminopeptidase -I (Lap) over Long Island Sound populations. All Coscinasterias muricata we sampled in the fjords were subtidal and from below the apparent freshwater layer. We rarely observed juveniles, but it is most likely that if settlement occurred within the LSL, the larvae would die, since echinoderm larvae in general are very sensitive to low salinity (Stickle \& Diehl 1987). Hedgecock (1986) suggested that genetic analysis alone is usually insufficient to determine whether population differentiation has resulted primarily through the restriction of larval dispersal or from natural selection and/or local adaptation. However, we believe that the populations within the fjords are exposed to similar selective pressures, and thus genetic differentiation between fjords should mainly be due to restriction of larval dispersal. In addition, the 4 loci examined all showed similar estimates of subdivision. However, it cannot be ruled out that balancing selection at these loci homogenises allele frequencies at different localities and thereby reduces genetic differentiation (Karl \& Avise 1992).

The life history of sexually reproducing populations of Coscinasterias muricata indicates a continuously distributed population. C. muricata has a planktonic larval stage of ca. 1 mo (Barker 1978). However, most populations studied also reproduce by fission (Crump \& Barker 1985, Johnson \& Threlfall 1987), and could produce clones. Asexual reproduction might reduce the effective population size and increase genetic drift. To address this potential problem, we used only unique genotypes in analysis of populations where recruitment from asexual reproduction was significant. None of the populations in the fjord region showed signs of individuals being split or had a lower ratio of observed versus expected genotypic diversity.

The observed differences in allele frequencies may be due to random genetic drift between isolated sites. However, gene flow and genetic drift require time to equilibrate (Slatkin 1993), and indirect estimates of gene flow from $F_{\text {st }}$ are based on many biologically unrealistic assumptions that most likely are violated
(Whitlock \& McCauley 1999). Isolation and random genetic drift can thus not be ruled out as important mechanisms behind the genetic structuring of Coscinasterias muricata in the fjords.

Assuming that the west coast populations are mainly restricted to the fjords, a correlation between gene flow and geographic separation would be expected, as the distribution of the fjords can be considered as a stepping-stone model in this region, where spatial differentiation arises between discrete populations assuming that only immediately adjacent populations exchange genes (Kimura \& Weiss 1964).

The hydrodynamics of each of the fjords is strongly influenced by freshwater input. This is a likely factor in the explanation of genetic isolation between the fjords, since circulation can strongly influence the dispersal of planktonic larvae. Estuarine circulation (see 'Introduction') is common to all the fjords, but will vary among fjords due to variation in freshwater input and bathymetry (Stanton \& Pickard 1981, Stanton 1984, Gibbs et al. 2000). Thus, the low salinity layer places controls on circulation and the transport of passive larvae within the fjord (Wing et al. 2003). Echinoderm larvae are sensitive to low salinities (Stickle \& Diehl 1987), and would either avoid them or die if exposed to low salinity for prolonged periods. During calm periods the flow in the oceanic layer beneath the LSL is likely to be directed in the up-fjord direction. These flows would act to retain larvae within the fjord. In contrast, during strong wind events the flow in the surface layer down to 15-20 m may be in the down-fjord or seaward direction (Gibbs et al. 2000), and passive larvae could be transported seaward and possibly lost from the fjord. This circulation would tend to result in loss of larvae that are near the entrance of the fjord and retention of larvae that are distributed near the head of the fjord. An investigation of origin and larval transport in the sea urchin Evechinus chloroticus within Doubtful Sound by Lamare (1998) supports this pattern. Lamare (1998) found high larval retention consistent with the estuarine circulation of the fjord, with lack of larvae in the surface layers of the fjord. We stress that the estuarine circulation is a likely explanation for why populations of Coscinasterias muricata in the fjords form genetic clusters that are inconsistent with geographical distance. Alternative to the isolation-by-distance or the stepping stone models, the population genetic structure on the regional scale of the fjords may thus rather conform to an island model, where migration occurs at random among a group of small populations, and mating is more frequent within than between populations. Limited plankton dispersal would result in subdivision of populations due to inbreeding (Knowlton \& Jackson 1993), as well as genetic drift and localized selection. 
In a similar study of genetic patterns in the New Zealand fjords, Miller (1997) found that in the anthipatharian black coral Anthipates fiordensis, a species with little dispersal, the fjord populations were genetically very similar. Suggested explanations were that the populations of this sexually and asexually reproducing, long-lived species were not in genetic equilibrium (Miller 1997). In addition, there is a high seeding potential to the fjords from the probably panmictic offshore population of A. fiordensis on the deep shelf. In comparison, Coscinasterias muricata shows genetic differentiation and is a coastal shallow water species with population densities peaking at 2 to $8 \mathrm{~m}$ in the fjords (Grange et al. 1981, Witman \& Grange 1998), with probably little seeding potential from the deep shelf off the coast.

The fjords were formed from freshwater lakes, beginning about $12000 \mathrm{yr}$ ago, and the fjord with the deepest sill was probably colonized first. The time (in generations) for a metapopulation to reach equilibrium is increased by low migration rates and population size, and can be extremely long if migration rates are low (Whitlock \& McCauley 1999). Due to recent colonization and limited larval dispersal, it may well be the case that the populations of Coscinasterias muricata in the fjords are not yet in genetic equilibrium.

\section{CONCLUSIONS}

Fjords can be important habitats for genetic differentiation, and our data suggest that the circulatory pattern of the New Zealand fjords may act to retain larvae within the them, and thus isolate the populations from the open coast and each other. The greatest potential for isolation should be for linearly distributed shallow water species with preferences for protected habitats. In a coastal region like the fjords of New Zealand, the population-genetic structure may thus conform to an island model where migration occurs at random among a group of small populations, i.e. the fjord populations, and mating is more frequent within than between populations. Our study also emphasizes the importance of considering the bio-geographic and oceanographic history when assessing genetic differentiation in marine environments.

Acknowledgements. We thank B. Walker, captain of the MV 'Renown', P. Meredith, M. Lamare, N. Goebel, P. Brewin, J. Vasques, H. Sköld, B. Gould and P. Stratford for technical assistance in the field, and the staff and management at Portobello Marine laboratory for help and laboratory facilities. Also thanks to G. P. Wallis and K. Judge for technical advice in allozyme methodology. We thank 4 anonymous referees and the editor J. M. Lawrence for constructive criticism of earlier versions of this manuscript. This study was financed by research grants from the Swedish Institute, the Wennergren Center Foundation for Scientific Research, the Helge-Ax:son Johnson foundation, the Royal Society of Arts and Sciences in Göteborg and the Royal Society for Physical Geography to M.S. and University of Otago Research Grants to S.R.W. and P.V.M.

\section{LITERATURE CITED}

Ayvazian SG, Johnson DJ, McGlashan DJ (1994) High levels of subdivision of marine and estuarine populations of the estuarine catfish Cnidoglanis macrocephalus (Plotosidae) in southeastern Australia. Mar Biol 118:25-31

Barber PH, Palumbi SR, Erdmann MV, Kasim Moosa M (2000) A marine Wallace's line? Nature 406:692-693

Barker MF (1977) Observations on the settlement of the brachiolaria larvae of Stichaster australis (Verril) and Coscinasterias calamaria (Gray) (Echinodermata: Asteroidea) in the laboratory and on the shore. J Exp Mar Biol Ecol 30: 95-108

Barker M (1978) Descriptions of the larvae of Stichaster australis (Verril) and Coscinasterias calamaria (Gray) (Echinodermata: Asteroidea) from New Zealand, obtained from laboratory culture. Biol Bull 177:32-46

Benzie AH (1999) Major genetic differences between crownof-thorns starfish (Acanthaster planci) populations in the Indian and Pacific oceans. Evolution 52:1782-1795

Benzie AH, Stoddart JA (1992) Genetic structure of crown-ofthorns starfish (Acanthaster planci) in Australia. Mar Biol 112:631-639

Bertness MD, Gaines SD (1993) Larval dispersal and local adaptation in acorn barnacles. Evolution 47:316-320

Burton RS, Feldman MW (1981) Population genetics of Tigriopus californicus. 2. Differentiation among neighbouring populations. Evolution 35:1992-1205

Crow JF, Aoki K (1984) Group selection for a polygenic trait: estimating the degree of population subdivision. Proc Natl Acad Sci USA 81:6037-6077

Crump RG, Barker MF (1985) Sexual and asexual reproduction in geographically separated populations of the fissiparous asteroid Coscinasterias calamaria (Gray). J Exp Mar Biol Ecol 88:109-127

Dobzhansky T (1937) Genetics and the origin of species. Columbia University Press, New York

Edmands S, Moberg PE, Burton RS (1996) Allozyme and mitochondrial DNA evidence of population subdivision in the purple sea urchin Strongylocentrotus purpuratus. Mar Biol 126:443-450

Emlet R, McEdward L, Strathmann RR (1987) Echinoderm larval ecology viewed from the egg. In: Jangoux M, Lawrence JM (eds) Echinoderm studies 2. AA Balkema, Rotterdam, p 55-136

Garrett FK, Mladenov PV, Wallis GP (1997) Evidence of amictic reproduction in the brittle-star Ophiomyxa brevirama. Mar Biol 129:169-174

Gibbs MT, Bowman MJ, Dietrich DE (2000) Maintenance of near-surface stratification in Doubtful Sound, a New Zealand fjord. Estuar Coast Shelf Sci 51:683-704

Goudet J (1995) FSTAT version 1.2: a computer program to calculate F-statistics. J Heredity 86:485-486

Grange KR, Singleton RJ, Richardsson JR, Hill PJ, Main WD (1981) Shallow rock-wall biological associations of some southern fiords of New Zealand. NZ J Zool 8:209-227

Haldane JBS (1954) An exact test for randomness of mating. J Genet 52:631-635

Hedgecock D (1986) Is gene flow from pelagic larval dispersal 
important in the adaptation and evolution of marine invertebrates? Bull Mar Sci 39:550-564

Hellberg ME (1994) Relationships between inferred levels of gene flow and geographic distance in a philopatric coral, Balanophyllia elegans. Evolution 48:1829-1854

Hollborn K, Johnson MS, Black R (1994) Population genetics of the corallivorous gastropod Drupella cornus at Ningalo Reef, western Australia. Coral Reefs 13:33-39

Hutchinson DW, Templeton AR (1999) Correlation of pairwise genetic and geographic distance measures: inferring the relative influences of gene flow and drift on the distribution of genetic variability. Evolution 53:1898-1914

Johnson MS, Black R (1984) Pattern beneath the chaos: the effect of recruitment on genetic patchyness in an intertidal limpet. Evolution 38:1371-1383

Johnson MS, Black R (1998) Effects of isolation by distance and geographical discontinuity on genetic subdivision of Littoraria cingulata. Mar Biol 132:295-303

Johnson MS, Threlfall TJ (1987) Fissiparity and population genetics of Coscinasterias calamaria. Mar Biol 93:517-525

Johnson MS, Creagh S, Moran M (1986) Genetic subdivision of stocks of snapper, Chrysophrys unicolor, in Shark Bay, Western Australia. Aust J Mar Freshw Res 37:337-345

Johnson MS, Watts RJ, Black R (1994) High levels of subdivision in peripherally isolated populations of the atherinid fish Craterocephalus capreoli in the Houtman Abrolhos Islands, Western Australia. Mar Biol 119:179-184

Jones GP, Milicich MJ, Emslie MJ, Lunow C (1999) Selfrecruitment in a coral reef fish populations. Nature 402: 802-804

Karl SA, Avise JC (1992) Balancing selection at allozyme markers in oysters: implications from nuclear RFLPs. Science 256:100-102

Kimura M, Weiss GH (1964) The stepping stone model of population structure and the decrease of genetic correlation with distance. Genetics 49:561-576

Knowlton N (1993) Sibling species in the sea. Annu Rev Ecol Syst 24:189-216

Knowlton N, Jackson JBC (1993) Inbreeding and outbreeding in marine invertebrates. In: Thornhill $N$ (ed) The natural history of inbreeding and outbreeding. University of Chicago Press, Chicago, p 200-249

Knowlton N, Weight LA, Solarenzo LA, Mills DK, Bermingham E (1993) Divergence in proteins, mitochondrial DNA, and reproductive compatibility across the Isthmus of Panama. Science 260:1629-1632

Koehn RKJ, Hall G, Innes DJ, Zera AJ (1984) Genetic differentiation of Mytilus edulis in eastern North America. Mar Biol 79:117-126

Lamare M (1998) Origin and transport of larvae of the sea urchin Evechinus chloroticus (Echinodermata: Echinoidea) in a New Zealand fiord. Mar Ecol Prog Ser 174: 107-121

Lessios HA, Cunningham CW (1990) Gametic incompatibility between species of the sea urchin Echinometra on 2 sides of the Isthmus of Panama. Evolution 44:933-941

Lessios HA, Weinberg JR (1993) Migration, gene flow, and reproductive isolation between and within morphotypes of the isopod Excirolana in 2 oceans. Heredity 71:561-573

Maestro E, Chow V, Hedgecock D (1982) Littorina scutulata and Littorina plena; sibling species status of 2 prosobranch gastropod species confirmed by electrophoresis. Veliger 24:239-246

Mantel N (1967) The detection of disease clustering and a generalized regression approach. Cancer Res 27:209-220

Mayr E (1942) Systematics and the origin of species. Columbia University Press, New York
Miller K (1997) Genetic structure of black coral populations in New Zealand's fiords. Mar Ecol Prog Ser 161:123-132

Mladenov PV, Emson RH (1990) Genetic structure of populations of two closely related brittle stars with contrasting sexual and asexual life histories, with observations on the genetic structure of a second asexual species. Mar Biol 104:265-274

Mladenov PV, Allibone RM, Wallis GP (1997) Genetic differentiation in the New Zealand sea urchin Evechinus chloroticus (Echinodermata). NZ J Mar Freshw Res 31:261-269

Nei M (1978) Estimation of average heterozygosity and genetic distance from small numbers of individuals. Genetics 89: $583-590$

Palumbi SR (1994) Genetic divergence, reproductive isolation, and marine speciation. Annu Rev Ecol Syst 25:547-572

Palumbi SR, Grabowsky G, Duda T, Geyer L, Tachino N (1997) Speciation and population genetic structure in tropical Pacific sea urchins. Evolution 51:1506-1517

Parsons KE (1996) The genetic effects of larval dispersal depend on spatial scale and habitat characteristics. Mar Biol 126:403-414

Pasteur N, Pasteur G, Bonhomme F, Catalan J, BrittonDavidian J (1988) Practical isozyme genetics. Ellis Horwood, Chichester

Pickrill RA, Fenner JM, McGlone MS (1992) Late Quarternary evolution of a fiord environment in Preservation Inlet New Zealand. Quat Res 38:331-346

Raymond M, Rousset F (1995) GENEPOP (Version 1.2): population genetics software for exact tests and ecumenicism. J Hered 86:248-249

Reid DG (1990) Trans-arctic migration and speciation induced by climatic change: the biogeography of Littorina (Mollusca: Gastropoda). Bull Mar Sci 47:35-49

Scheltema RS (1975) Relationship of larval dispersal, gene-flow and natural selection to geographic variation of benthic invertebrates in estuaries and along coastal regions. In: Cronin LE (ed) Estuarine research. I. Chemistry, biology and the estuarine system. Academic Press, New York, p 372-391

Selander RK, Smith MH, Yang SY, Johnson WE, Gentry JB (1971) Biochemical polymorphism and systematics in the genus Peromyscus. I. Variation in the old-field mouse Peromyscus polionotus. Stud Genet 6:49-90

Shaw CR, Prasad R (1970) Starch gel electrophoresis of enzymes-a compilation of recepies. Biochem Genet 4: $297-320$

Sköld M, Barker MF, Mladenov PV (2002) Spatial variability in sexual and asexual reproduction in the fissiparous seastar Coscinasterias muricata: the role of food and fluctuating temperature. Mar Ecol Prog Ser 233:143-155

Slatkin M (1993) Isolation by distance in equilibrium and nonequilibrium populations. Evolution 47:264-279

Smith F, Witman JD (1999) Species diversity in subtidal landscapes: maintenance by physical processes and larval recruitment. Ecology 80:51-69

Sokal RR, Rohlf FJ (1995) Biometry. WH Freeman, New York

Stanton BR (1984) Some oceanographic observations in the New Zealand fjords. Estuar Coast Shelf Sci 19:89-104

Stanton BR, Pickard GL (1981) Physical oceanography of the New Zealand fiords. New Zealand Oceanographic Institute Memoir 88. New Zealand Department of Scientific and Industrial Research, Wellington

Stickle WB, Diehl WJ (1987) Effects of salinity on echinoderms. In: Jangoux M, Lawrence JM (eds) Echinoderm studies 2. AA Balkema, Rotterdam, p 235-285

Stoddart JA (1983) A genotypic diversity measure. J Hered 74:489-490

Swearer SE, Caselle JE, Lea DW, Warner RR (1999) Larval 
retention and recruitment in an island population of a coral-reef fish. Nature 402:799-802

Swofford DI, Selander RB (1989) BIOSYS-1. A Fortran program for the comprehensive analysis of electrophoretic data in population genetics and systematics. J Hered 72: 281-283

Watts RJ, Johnson MS, Black R (1990) Effects of recruitment on genetic patchyness in the urchin Echinometra mathaei in western Australia. Mar Biol 105:145-151

Weir BS (1990) Genetic data analysis. Sinauer, Sunderland Weir BS, Cockerham CC (1984) Estimating F-statistics for the analysis of population structure. Evolution 38:1358-1370

Whitlock MC, McCauley DE (1999) Indirect measures of gene flow and migration: $\mathrm{F}_{\mathrm{st}} \neq 1 /(4 \mathrm{Nm}+1)$. Heredity $82: 117-125$

Editorial responsibility: John Lawrence (Contributing Editor), Tampa, Florida, USA
Williams ST, Benzie JAH (1993) Genetic consequences of long larval life in the starfish Linckia laevigata (Echinodermata: Asteroidea) on the Great Barrier Reef. Mar Biol 117:71-77

Wing SR, Gibbs MT, Lamare MD (2003) Reproductive sources and sinks within the sea urchin (Evechinus chloroticus) population of a New Zealand fjord. Mar Ecol Prog Ser 248: 109-123

Witman JD, Grange KR (1998) Links between rain, salinity, and predation in a rocky subtidal community. Ecology 79 : 2429-2447

Wright S (1943) Isolation by distance. Genetics 28:114-138

Wright S (1978) Evolution and the genetics of populations. University of Chicago Press, Chicago

Submitted: February 13, 2002; Accepted: December 3, 2002 Proofs received from author(s): March 10, 2003 